\title{
Gene Expression Profiles of the Rat Cochlea, Cochlear Nucleus, and Inferior Colliculus
}

\author{
Younsook Cho, ${ }^{1,2}$ Tzy-Wen L. Gong, ${ }^{2}$ Timo Stöver,,${ }^{2,3}$ Margaret I. Lomax, ${ }^{1,2}$ And \\ Richard A. Altschuler ${ }^{1,2}$ \\ ${ }^{1}$ Department of Cell and Developmental Biology, University of Michigan Medical School, Ann Arbor, MI 48109, USA \\ ${ }^{2}$ Kresge Hearing Research Institute, Department of Otolaryngology/ Head-Neck Surgery, University of Michigan Medical School, \\ Ann Arbor, MI 48109, USA \\ ${ }^{3}$ Department of Otolaryngology, Medical University of Hannover, Hannover, Germany
}

Received: 14 April 2000; Accepted: 25 June 2001; Online publication: 3 October 2001

\begin{abstract}
High-throughput DNA microarray technology allows for the assessment of large numbers of genes and can reveal gene expression in a specific region, differential gene expression between regions, as well as changes in gene expression under changing experimental conditions or with a particular disease. The present study used a gene array to profile normal gene expression in the rat whole cochlea, two subregions of the cochlea (modiolar and sensorineural epithelium), and the cochlear nucleus and inferior colliculus of the auditory brainstem. The hippocampus was also assessed as a well-characterized reference tissue. Approximately $40 \%$ of the 588 genes on the array showed expression over background. When the criterion for a signal threshold was set conservatively at twice background, the number of genes above the signal threshold ranged from approximately $20 \%$ in the cochlea to $30 \%$ in the inferior colliculus. While much of the gene expression pattern was expected based on the literature, gene profiles also revealed expression of genes that had not been reported previously. Many genes were expressed in all regions while others were differentially expressed (defined as greater than a twofold difference in expression between regions). A greater number of differentially expressed genes were found when comparing peripheral (cochlear) and central nervous system
\end{abstract}

Correspondence to: Richard A. Altschuler, Ph.D. • Department of Cell and Developmental Biology • Kresge Hearing Research Institute • University of Michigan • 1301 E. Ann Street • Ann Arbor, MI 48109. Telephone: (734) 763-0060; fax: (734) 764-0014; email: shuler @umich.edu regions than when comparing the central auditory regions and the hippocampus. Several families of insulin-like growth factor binding proteins, matrix metalloproteinases, and tissue inhibitor of metalloproteinases were among the genes expressed at much higher levels in the cochlea compared with the central nervous system regions.

Keywords: Gene array, DNA microarray, gene expression, hippocampus, inferior colliculus, cochlear nucleus, cochlea

\section{INTRODUCTION}

Expressed genes can, in general, be divided into two classes: (1) housekeeping genes that are ubiquitously expressed and (2) tissue-specific genes. Housekeeping genes are thought to be necessary for the normal maintenance of the structural and functional integrity of most, if not all, cells. Tissue-specific genes, by definition, have a restricted pattern of expression and would be expected to provide important information about the specific structures and functions of a specific tissue. Ideally, one would like to develop complete gene expression profiles of a particular cell or tissue by analyzing all of the 50,000 or so genes predicted to occur in mammalian genomes. That subset of genes expressed in a particular tissue or organism has been termed the "transcriptome," the repertoire of transcribed genes that define that tissue or cell type. However, smaller subsets can still provide considerable information and enhance our understanding of the cells and/or tissue assessed. 
In the auditory system, most functionally important genes and proteins have been identified through mutational studies, through subtractive hybridization, or through differential display. Application of subtractive hybridization to a human fetal cochlear cDNA library identified 1449 previously characterized known genes at http://hearing.bwh.harvard.edu/ cochlearcdnalibrary.htm/ as of December 2000. They include several subtypes of collagen genes and peripheral myelin protein (PMP-22), as well as novel cochlear genes (Robertson et al. 1994; Skvorak et al. 1999). A polymerase chain reaction (PCR)-based differential display study of the chick basilar papilla after acoustic trauma revealed that the $\delta$ subunit of the neuronalspecific $\mathrm{Ca}^{2+} /$ calmodulin-regulated kinase II (CAMK II) and CDC 42, a GTP-binding protein, were up-regulated in the chick basilar papilla exposed to noise (Gong et al. 1996). However, the large number of novel genes identified by this method and the amount of characterization needed to complete these studies in general represents a considerable investment of labor and time.

Gene arrays or DNA microarrays, which contain large numbers of cDNA sequences that represent specific genes, allow the simultaneous assessment of expression of multiple genes in specific tissue types with very little material in a relatively short period of time (for review, see Nature Genetics Supplement 21:1, 1999). Profiling gene expression is a powerful method for characterizing specific tissues, for comparing gene expression between regions, and for determining differential gene expression under varying experimental conditions. For example, a study using DNA microarrays containing probes for almost the complete set of yeast genes showed that genes containing consensus sequences for the transcription factor $\mathrm{Ndt} 80$ are important for meiotic prophase in budding yeast during spore development (Chu et al. 1998). DNA microarrays are therefore an excellent tool to provide a global view of biological processes in an efficient way.

This study used a cDNA array to characterize and compare normal gene expression patterns in several regions of the auditory pathway: (a) the cochlear nucleus $(\mathrm{CN})$, (b) the inferior colliculus (IC), (c) the whole cochlea (WC), (d) two cochlear subfractionsthe modiolus (MOD) and the sensorineural epithelium (SE). The MOD contains the cell bodies of the auditory nerve and supporting cells, and the SE contains the organ of Corti, supporting cells, and the lateral wall. The hippocampus (HP) was chosen as a well-known and nonauditory tissue to potentially identify auditory region-specific genes. The first level of assessment generated a gene expression profile for each region. A second level of assessment compared expression patterns among regions to determine genes that are differentially expressed. Finally six genes in the cochlea with high expression relative to the other regions were selected and their expression confirmed and compared among regions using semiquatitative reverse transcriptase (RT)-PCR.

\section{METHODS}

\section{Gene array}

The Atlas ${ }^{\mathrm{TM}}$ cDNA expression array (Catalog \# 77381 , Clontech, Palo Alto, CA, USA) is a nylon membranetype gene array and contains 588 known rat genes plus 9 housekeeping genes. A 200-800 bp long PCR product of each cDNA representing species-specific genes was microspotted in duplicate spots containing $10 \mathrm{ng} /$ dot. The genes are grouped into six blocks. Each block contains functionally related genes (for more detail, see the home page of Clontech at http:// www.clontech.com).

\section{RNA extraction}

Sprague-Dawley male rats (200-250 g, 8-12 weeks) were deeply anesthesized with $35 \%(\mathrm{w} / \mathrm{v})$ chloral hydrate $(350 \mathrm{mg} / \mathrm{kg}, \mathrm{IP})$ and decapitated. Brains were removed and the $\mathrm{HP}$, IC, and $\mathrm{CN}$ were dissected and placed in $1 \mathrm{~mL}$ of lysis buffer containing $4 \mathrm{M}$ guanidium thiocynate, $25 \mathrm{mM}$ sodium citrate $(\mathrm{pH} 7.0), 0.5 \%$ sarcosyl, and 0.1 M 2-mercaptoethanol per $100 \mathrm{mg}$ wet tissue (Chomczynski and Sacchi 1987). After the brains the temporal bones were removed and dissected in ice-cold RNase-free PBS to collect the cochleae. The otic capsule was removed and the remaining WC with the lateral wall still largely attached was placed in 2 $\mathrm{mL}$ of lysis buffer. Alternatively, the WC was further dissected to separate the SE with some lateral wall still attached from the modiolar core containing largely the auditory nerve and spiral ganglion, glial cells, and vascular elements. The cochlear material from six to eight animals was pooled for the WC and the MOD, and from 20 animals for the SE fraction. The tissues were homogenized for $1 \mathrm{~min}$ at speed 5 with a Polytron $^{\mathrm{TM}}$ homogenizer (Brinkman, Westbury, NY). The homogenized tissues were kept at $-70^{\circ} \mathrm{C}$ until RNA isolation. Total RNA was extracted from the homogenized tissues with SV Total RNA Isolation System (Promega, Madison, WI, USA). The yield of total RNA ranged from 0.5 to $1 \mu \mathrm{g}$ per WC. Our experience indicated that the proportion of RNA obtained from each subfraction was 1:4 for the SE and the MOD.

\section{Probe synthesis and hybridization}

Radiolabeled cDNA was synthesized according to the vendor's protocol with a slight modification (Clontech). Reverse transcriptase reaction was performed 
on $2 \mu \mathrm{g}$ of total RNA in $10 \mu \mathrm{L}$ of a reaction mixture containing $20 \mathrm{nM}$ each of gene-specific primers; 500 $\mu \mathrm{M}$ each of dCTP, dGTP, and dTTP; $35 \mu \mathrm{Ci}$ of $\alpha^{32} \mathrm{P}$ dATP $(3000 \mathrm{Ci} / \mathrm{mmol})$; and $100 \mathrm{U}$ of MMLV reverse transcriptase Superscript II (Life Technologies Inc., Gaithersburg, MD, USA) for $25 \mathrm{~min}$ at $50^{\circ} \mathrm{C}$. cDNA probe was purified by passage through CHROMA SPIN-200 DEPC- $\mathrm{H}_{2} \mathrm{O}$ columns (Clontech), and final probe concentration was adjusted to $1-2 \times 10^{6} \mathrm{cpm} /$ $\mathrm{mL}$ in $10 \mathrm{~mL}$ of ExpressHyb ${ }^{\mathrm{TM}}$ by hybridization solution (Clontech). Hybridization to Atlas Rat cDNA Expression Array was carried out overnight at $68^{\circ} \mathrm{C}$. The membranes were washed four times in $2 \times \mathrm{SSC} / 1 \% \mathrm{SDS}$ at $68^{\circ} \mathrm{C}$ for $30 \mathrm{~min}$ each and two more times in $0.1 \times \mathrm{SSC} /$ $0.5 \% \mathrm{SDS}$ at $68^{\circ} \mathrm{C}$ for $30 \mathrm{~min}$ each and exposed to a Storage Phosphor screen for phosphor imaging overnight. The screen was scanned with phosphor imager 445 SI (Molecular Dynamics, Sunnyvale, CA, USA).

In order to determine the variation among membranes, the cDNA probes of RNA from each of the three brain regions-the $\mathrm{HP}$, IC, and $\mathrm{CN}$-were hybridized to duplicate membranes in the same experiment. Duplicate membranes from each region of the brain were analyzed and compared. The reproducibility of the experimental results was assessed by repeated hybridization of three brain regions ( $\mathrm{HP}, \mathrm{IC}$ and $\mathrm{CN}$ ) and the WC RNA sample and comparing two experiments in each region.

\section{Data analysis}

Image files obtained from phosphor imaging were analyzed with AtlasImage v1.01 software (Clontech). The signal intensity for each gene was the average signal from duplicate spots and corrected for the background signal on each membrane. The signal threshold was set at $100 \%$ over background signal (\{ (Signal ${ }_{\text {gene } Z \text {,arrayl }}$ - Background arrayl )/Background arrayl $\left._{\text {Ba }}\right\} \geq 1$ ). In the Results section, signals are referred to as either above or below these defined thresholds. For the three brain regions and the $\mathrm{WC}$, two or three membranes from two hybridization experiments were averaged using the AtlasImage software; the averaged values were used for normal gene expression profiles and subsequent comparisons of each region. For the normal gene expression, the expression level of mRNA was displayed as a relative intensity to the background of averaged array. For the comparison among regions, signals from one region were normalized to the other one using at least two out of the nine housekeeping genes in the array to adjust for variation in experimental conditions such as differences in specific activity and the concentration of labeled cDNA, hybridization conditions, and exposure time. The threshold of the ratio of the signal from one array to the other array was set at 2.0 and that of the signal difference was set at the summation of each background signal of two arrays $\left(\right.$ Background $_{\text {arrayl }}+$ Background $_{\text {array2 }}$ ). For the comparisons of cochlear subfractions, a single array from each region (WC, MOD, and SE) was used.

\section{Sensitivity and threshold considerations}

Under our experimental conditions, $40 \%-50 \%$ of the 588 genes on the arrays showed expression over background in the brain tissues. However, when we applied our criterion for a signal threshold of $100 \%$ over background (twice background), expression was found in $20 \%-30 \%$ of the genes on the array. In order to evaluate variability among membranes, duplicate membranes were hybridized with the brain tissues. Figure 1A shows membrane variability in the case of the hippocampus. When the corrected signals to the background of one membrane were plotted to $x$ axis and those of the other membrane to $y$ axis, most of genes with the signal threshold $100 \%$ over background fell within the signal ratio 2:0.5 which we set for significant differential expression between two regions. If we lowered the detection limit to $50 \%$ over background, then $30 \%-40 \%$ of the 588 genes had positive signals, i.e., had expression above this lower threshold level. However, this significantly decreased the reproducibility of the signals between duplicate membranes. Therefore, we chose to be conservative and defined $100 \%$ of the signal threshold (twice background) as the necessary condition for a positive result in this study. It should be noted that many genes whose mRNA is in the low to modest abundance class in the mRNA population being assayed will fall below the detection criterion we have set.

Figure $1 \mathrm{~B}$ displays the experimental variation of two hybridizations with the hippocampus RNA. The signal differences of the genes with over twice background in both hybridizations, shown in the upper-right corner of the square, were less than twofold. Several genes with the signals below the threshold in either experiment (upper-left and lower-right corner of the square) showed more than a twofold difference between two experiments. For comparison analysis, we therefore applied the very stringent thresholds as the signal difference at twice background as well as the signal ratio at twofold.

Housekeeping genes generally are used for normalizing signals between two arrays being compared. It is possible that the expression levels of the housekeeping genes are themselves different among regions or under experimental conditions. Thus, we compared two different normalization methods. The "global method" calculates a normalization coefficient based on the sum of the values of signal over background for all genes on the arrays. The "housekeeping gene method" calculates the normalization coefficient 


\section{A. Membrane variability}

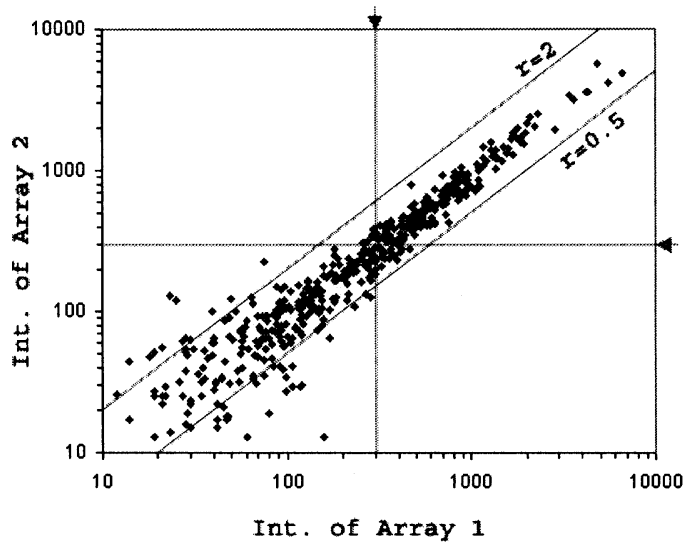

FIG. 1. Experimental variability of gene expression profiles. For each gene, the corrected intensity to the background in one array is given on the $x$ axis and the corrected intensity in the other array is plotted on the $y$ axis. Twofold changes $(r=$ intensity in array 2/ intensity in array $1>2$ or $<0.5$ ) are indicated. The arrow indicates the signal threshold (twice background) of each membrane. A Comparison of duplicate membranes. Hippocampal total RNA (2 $\mu \mathrm{g})$ was

according to the average of the signal ratios of the housekeeping genes being selected. The two methods resulted in very similar data in the comparisons of two CNS regions or cochlear subfractions but showed a large difference in the comparison of the cochlea to any CNS region. The normalization coefficient of the global method for the comparison of the cochlea to the hippocampus was $50 \%$ higher than that of the housekeeping gene method. We believed that this was because, considering that most genes on the array were well characterized in other tissues such as the brain, many more genes on the array could be expressed in CNS regions, biasing results from the global method. The present study therefore chose to make comparisons using the housekeeping gene normalization.

\section{Semiquantitative RT-PCR and data analysis}

For RT-PCR, $1 \mu \mathrm{g}$ total RNA of HP, IC, CN, WC, MOD, and SE was reverse transcribed into single-stranded cDNA with SuperScript II MMLV reverse transcriptase (Life Technologies Inc.) using oligo $(\mathrm{dT})_{12-18}$ as primers in $20 \mu \mathrm{L}$ of a reaction mixture. The reaction mixture was diluted tenfold with RNase-free water and then stored at $-20^{\circ} \mathrm{C}$ for subsequent PCR analysis.

The sequences of oligonucleotide primers for two housekeeping genes, polyubiquitin and beta actin, and the following six genes were purchased from Clontech: LIM domain kinase-1 (LIMK-1), insulin-like growth factor binding protein-2 (IGFBP-2), IGFBP-6, gelatinase A/matrix metalloproteinase-2 (MMP-2), membrane type MMP-1 (MT MMP-1/MMP-14), and tissue inhibitor of metalloproteinase-3 (TIMP-3). A $5 \mu \mathrm{L}$ aliquot of the diluted cDNA strand was subjected to PCR

\section{B. Experimental variability}

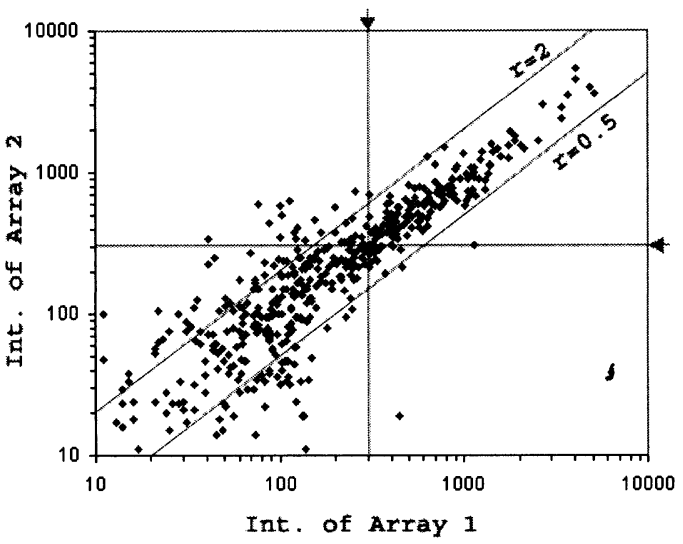

converted into ${ }^{32} \mathrm{P}$-radiolabeled cDNA and hybridized to duplicate arrays (array 1 and array 2). B Comparison of duplicate hybridizations. Hybridization was performed twice with the same hippocampal RNA and after normalization with housekeeping genes. The array 1 of the first experiment was compared with the array 2 of the second experiment.

amplification using the AmpliTaq Gold ${ }^{\mathrm{TM}}$ (Applied Biosystems, Boston, MA, USA) in $25 \mu \mathrm{L}$ of a reaction mixture. PCR conditions were $94^{\circ} \mathrm{C}$ for $10 \mathrm{~min}$ followed by 30 cycles of $94^{\circ} \mathrm{C}$ for $1 \mathrm{~min}$ and $68^{\circ} \mathrm{C}$ for 1 min. For the housekeeping genes polyubiquitin and beta actin, the lower number of PCR cycles, 27 and 25 cycles, respectively, were applied. Ten microliters of the PCR reaction aliquot was mixed with $1 \mu \mathrm{g}$ of ethidium bromide and run on $1.5 \%$ of agarose gel. The agarose gel was scanned with a gel documentation system (AlphaEase $^{\mathrm{TM}}$ v.3.24; Alpha Innotech Corporation, San Leandro, CA, USA) and the image files from the GelDoc system were quantified with IPLab software (Scanalytics, Fairfax, VA, USA). The variation of the signals from the input of RNA and the efficiency of the RT reaction were normalized with the two housekeeping genes. The values of intensities were averaged from two or three PCR experiments.

\section{RESULTS}

In the text, we provide results on genes showing differential expression in auditory regions. Image files for filter hybridization and lists of all genes expressed over background in each region are available on the Kresge Hearing Research Institute webpage at the University of Michigan (www.khri.med.umich.edu/genearray/).

\section{Expression profile of the whole cochlea}

In the whole cochlea, approximately $20 \%$ (102) of the genes (588) on the array showed expression levels $100 \%$ over background. The table containing the list of 
genes and the filter hybridization image are available at www.khri.med.umich.edu/genearray/. Twenty-eight of these genes, including TIMP-3, have previously been detected in the Morton human fetal cochlear cDNA library (http://hearing.bwh.harvard.edu/cochlear cdnalibrary.htm). In this study, we demonstrated expression of many additional genes that have not yet been reported in the cochlear cDNA library.

Many genes with significant signals were expected based on previous reports of their expression or the presence of their product in the cochlea, e.g., the trk B receptor (Ylikoski et al. 1993), neuron-specific enolase (Altschuler et al. 1985), and glutathione Stransferase (el Barbary et al. 1993). PMP-22 was reported in the human cochlea cDNA library while we would expect myelin proteolipid protein (PLP) and other proteins to be present based on our knowledge of cochlear histology. These arrays, however, also showed expression of several genes in the whole cochlea that have not been previously reported, including membrane glycoprotein gp130, Crk adaptor protein, PKC inhibitor protein-1, syntaxin binding protein, clusterin, G(i) $\alpha 2$ subunit, IGFBP-6, and TIMP-2.

Genes with particularly high expression in the whole cochlea (at least 5 times over background) included copper-zinc-containing superoxide dismutase 1 (Cu-Zn SOD 1), calmodulin, PMP-22, and the $\mathrm{Na}^{+} / \mathrm{K}^{+}$-ATPase $\alpha 1$ subunit. Several genes, whose expression would be predicted based on the literature, were expressed over background but fell below the exclusion criterion (twice background). These genes included fibroblast growth factor receptor 1 (http:// hearing.bwh.harvard.edu/cochlearcdnalibrary), P2X(2) receptor (Housley et al. 1999; Jarlebark et al.2000), and NMDAR1 (Kuriyama et al. 1993; Niedzielski and Wenthold 1995; Safieddine and Eybalin 1992).

\section{Cochlear subfractions}

Figure 2 shows comparison of gene expression profiles among cochlear subfractions. There was little difference between gene expression profiles of the modiolar subfraction and gene expression profiles of the whole cochlea (Fig. 2A), as might be expected, since RNA from the MOD comprises approximately $80 \%$ of the whole cochlear RNA. On the other hand, when expression in the SE was compared with that in the WC, six genes showed increased expression in the SE: Ear-3, presomatotropin, synaptobrevin 2 (SYB2), corticosteroid 11- $\beta$-dehydrogenase isozyme 1 , IGFBP-2, and heparin-binding growth-associated protein (Fig. 2B and Table 1). Four genes had lower expression, suggesting they were much more highly expressed in the modiolus such as (not surprisingly) PLP. A comparison
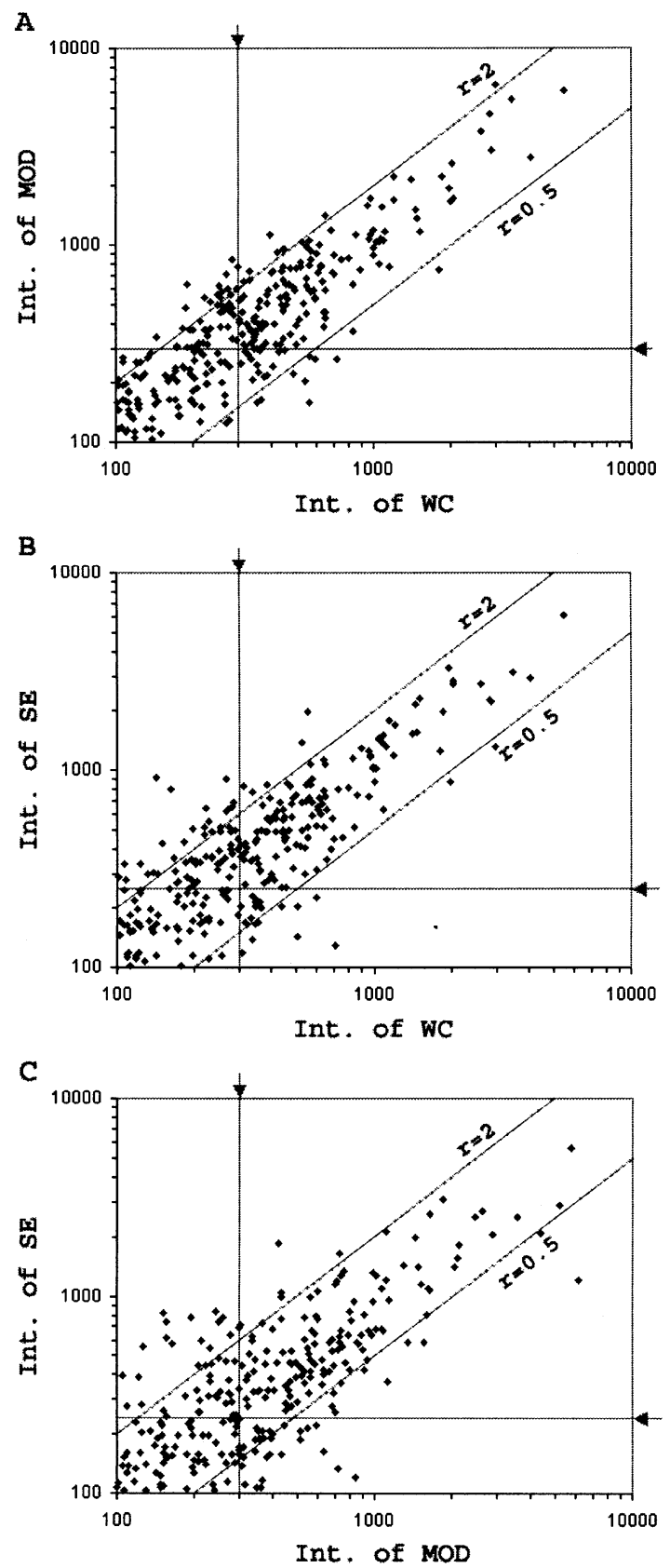

FIG. 2. Comparison of gene expression profiles of the cochlear subfractions. Total RNA $(2 \mu \mathrm{g})$ from the whole cochlea (WC), the modiolus (MOD), or the sensorineural epithelium (SE) was converted into ${ }^{32} \mathrm{P}$-radiolabeled cDNA and hybridized to membranes. Twofold changes $(r=$ intensity in array $2 /$ intensity in array $1>2$ or $<0.5)$ are indicated. The arrow indicates the signal threshold (twice background) of each membrane. A MOD vs. WC. The intensity of the array hybridized with the WC RNA is plotted on the $x$ axis and, after normalization, the intensity of the array hybridized with the modiolar (MOD) RNA is plotted on the $y$ axis. B SE vs. WC. The intensity of the array hybridized with the WC RNA is plotted on the $x$ axis and, after normalization, the intensity of the array hybridized with the sensorineural epithelium (SE) RNA is plotted on the $y$ axis. C SE vs. MOD. The intensity of the array hybridized with the MOD RNA is plotted on the $x$ axis and, after normalization, the intensity of the array hybridized with the sensorineural epithelium (SE) RNA is plotted on the $y$ axis. Twofold changes $(r=$ intensity in array $2 /$ intensity in array $1>2$ or $<0.5)$ are indicated. The arrow indicates the signal threshold (twice background) for each membrane. 


\begin{tabular}{|c|c|c|c|}
\hline \multicolumn{4}{|c|}{ TABLE 1} \\
\hline \multicolumn{4}{|c|}{ List of genes differentially expressed in the cochlear subfractions ${ }^{\text {a }}$} \\
\hline Location & Protein/gene & Ratio $^{\mathrm{b}}$ & Difference ${ }^{\mathrm{c}}$ \\
\hline & Higher expression in SE compared with WC & & \\
\hline $\mathrm{A} 4 \mathrm{k}^{\mathrm{e}}$ & Insulin-like growth factor binding protein 2 (IGF-binding protein 2; IGFBP2; IBP2) & 3.6 & 1446 \\
\hline $\mathrm{F} 2 \mathrm{~h}$ & Heparin-binding growth associated protein & 2.6 & 855 \\
\hline $\mathrm{D} 2 \mathrm{~h}$ & Corticosteroid 11-beta-dehydrogenase isozyme 1 (11-DH) & $-\mathrm{d}$ & 772 \\
\hline $\mathrm{A} 2 \mathrm{n}$ & Ear-3; V-erbA related protein; COUP-TFI transcription factor & - & 639 \\
\hline $\mathrm{F} 3 \mathrm{~h}$ & Presomatotropin & - & 634 \\
\hline \multirow[t]{2}{*}{$\mathrm{C} 7 \mathrm{f}$} & Synaptobrevin 2 (SYB2); vesicle-associated membrane protein 2 (VAMP2) & - & 567 \\
\hline & Lower expression in SE compared with WC & & \\
\hline C3f & Myelin proteolipid protein (PLP); DM-20; lipophilin & 0.4 & -1651 \\
\hline A7d & Copper-zinc-containing superoxide dismutase 1 (Cu-Zn SOD1) & 0.4 & -1108 \\
\hline B6f & Sec1; syntaxin binding protein 1 ; UNC-18A; UNC-18-1; N-SEC1; RBSEC1 & 0.4 & -813 \\
\hline \multirow[t]{2}{*}{$\mathrm{C} 6 \mathrm{c}$} & Neuronatin & - & -574 \\
\hline & Higher expression in SE compared with MOD & & \\
\hline $\mathrm{A} 4 \mathrm{k}^{\mathrm{e}}$ & Insulin-like growth factor binding protein 2 (IGF-binding protein 2; IGFBP2; IBP2) & 4.4 & 1423 \\
\hline D5b & $40 S$ ribosomal protein S17 (RPS17) & 2.3 & 921 \\
\hline $\mathrm{D} 2 \mathrm{~h}$ & Corticosteroid 11-beta-dehydrogenase isozyme 1 (11-DH) & - & 809 \\
\hline $\mathrm{C} 7 \mathrm{n}$ & P2X purinoceptor 2; ATP receptor P2X2; purinergic receptor & - & 669 \\
\hline A3I & Sky proto-oncogene; Tyro3; Rse; Dtk & 2.4 & 614 \\
\hline $\mathrm{A} 2 \mathrm{n}$ & Ear-3; V-erbA related protein; COUP-TF1 transcription factor & - & 594 \\
\hline A6k & DNA topoisomerase II alpha (TOP2A) & - & 588 \\
\hline \multirow[t]{2}{*}{$\mathrm{F} 3 \mathrm{~h}$} & Presomatotropin & - & 582 \\
\hline & Lower expression in SE compared with MOD & & \\
\hline C3f & Myelin proteolipid protein (PLP); DM-20; lipophilin & 0.2 & -4969 \\
\hline $\mathrm{C} 3 \mathrm{~h}$ & SR13 myelin protein; peripheral myelin protein 22 (PMP-22); CD25 protein & 0.5 & -2302 \\
\hline B6f & Sec1; syntaxin binding protein 1; UNC-18A; UNC-18-1; N-SEC1; RBSEC1 & 0.4 & -974 \\
\hline $\mathrm{C} 2 \mathrm{C}$ & Rac-alpha serine/threonine kinase (RAC-PK-alpha); protein kinase B (PKB); AKT1 & - & -929 \\
\hline $\mathrm{B} 3 \mathrm{k}$ & LIM domain serine/threonine kinase 1 (LIMK1) & - & -759 \\
\hline C5e & Neuroendocrine protein 7B2 precursor; secretogranin V; SGNE1 & 0.4 & -756 \\
\hline $\mathrm{C} 6 \mathrm{c}$ & Neuronatin & - & -729 \\
\hline $\mathrm{D} 4 \mathrm{j}$ & $60 S$ ribosomal protein L44; L36A & - & -594 \\
\hline
\end{tabular}

asingle array for each region was used for comparison.

bRatio = adjusted intensity of SE array/adjusted intensity of WC array (or MOD).

${ }^{c}$ Difference $=$ adjusted intensity of SE array - adjusted intensity of WC array (or MOD).

$\mathrm{d}_{-}=$the signal ratio was not calculated when the adjusted intensity is background level in either array.

${ }^{\mathrm{e}}$ Gene chosen for RT-PCR assay.

between the SE and MOD subfractions also identified genes with differential expression (Fig. 2C and Table 1). For instance, the $\mathrm{P} 2 \mathrm{X}(2)$ receptor was more enriched in the SE subfraction than in the MOD. This result is consistent with the report of its localization (Housley et al. 1999; Jarlebark et al. 2000).

\section{Expression in the cochlear nucleus}

In the $\mathrm{CN}$, approximately $25 \%$ of the genes on the array showed expression levels $100 \%$ over background (www.khri.med.umich.edu/genearray/). Many of these levels were consistent with levels published in previous literature which looked at the specific gene or its product. They include trkB receptor (Hafidi et al. 1996), neurotransmitter receptor-related genes such as somatostatin (Wynne and Robertson, 1997), glycine receptor (GlyR) $\alpha 1$ (Friauf et al. 1997; Sato et al. 1995), NR-1 (Sato et al. 1998), GluR-4 (Hunter et al. 1993), and GABA-BR (Juiz et al. 1994). Other genes whose expression might be expected include channelrelated genes such as $\mathrm{Na}^{+} / \mathrm{K}^{+}$-ATPase $\alpha 1$ and $\beta 3$ subunits, chloride channel 1 (RCL1), delayed-rectifier $\mathrm{K}^{+}$ channel, and $\mathrm{Na}^{+}$channel 1 , as well as synapsins, glutamate transporter (GluT), and the glycine transporter.

Several genes, whose expression had been reported in the cochlear nucleus or was expected based on what is known about $\mathrm{CN}$ function, had expression levels above background but fell below our criterion for $100 \%$ over background: the neuronal acetylcholine receptor (AchR) $\beta$ subunit, GluR2, GluR1, GluR3, mGluR1, GABA-AR $\gamma$, and 2GABA-AR $\delta$.

\section{Expression in the inferior colliculus}

In the inferior collicus (IC) approximately $30 \%$ of the genes on the microarray showed expression levels $100 \%$ over background (www.khri.med.umich.edu/ 


\begin{tabular}{|c|c|c|c|}
\hline \multicolumn{4}{|c|}{ TABLE 2} \\
\hline \multicolumn{4}{|c|}{ List of genes differentially expressed in the central auditory brainstem ${ }^{\mathrm{a}}$} \\
\hline Location & Protein/gene & Ratio $^{\mathrm{b}}$ & Difference ${ }^{\mathrm{c}}$ \\
\hline & ligher expression in the $\mathrm{CN}$ compared with the IC & & \\
\hline D7i & Signal transducer CD24 precursor, heat stable antigen (HAS); nectadrin & 6.6 & 1693 \\
\hline $\mathrm{C} 7 \mathrm{C}$ & Glycine receptor (GlyR) alpha-1 chain precursor (48 kDa); strychnine binding subunit & 2.7 & 890 \\
\hline E6f & Cardiac delayed-rectifier potassium channel protein & 2.8 & 734 \\
\hline B5j & Transducin beta-1 subunit; GTP-binding protein G(i)/G(s)/G(t) beta subunit 1 & 2.3 & 683 \\
\hline $\mathrm{F} 2 \mathrm{~g}$ & Insulin-like growth factor II (IGF-II) & 8.0 & 600 \\
\hline A4k & Insulin-like growth factor binding protein 2 (IGF-binding protein 2; IGFBP2; IBP2) & $-^{d}$ & 780 \\
\hline C7e & Synaptobrevin 1 (SYB1); vesicle-associated membrane protein 1 (VAMP1) & - & 779 \\
\hline & ower expression in the $\mathrm{CN}$ compared with the IC & & \\
\hline $\mathrm{C} 4 \mathrm{~h}$ & Neuromodulin; axonal membrane protein GAP43; PP46; B-50 & 0.1 & -1805 \\
\hline $\mathrm{C} 7 \mathrm{k}$ & GABA-B receptor $1 \mathrm{a}+\mathrm{GABA}-\mathrm{B}$ receptor $1 \mathrm{~b}$ & 0.4 & -1154 \\
\hline E7l & GABA-A receptor beta-2 subunit precursor & - & -913 \\
\hline B1e & BDNF/NT-3 growth factor receptor precursor; trkB tyrosine kinase & 0.4 & -694 \\
\hline $\mathrm{C} 6 \mathrm{c}$ & Neuronatin & 0.4 & -616 \\
\hline
\end{tabular}

${ }^{a}$ Averaged values of three arrays for each region were used for comparison.

${ }^{b}$ Ratio = adjusted intensity of $\mathrm{CN}$ array/adjusted intensity of IC array.

${ }^{c}$ Difference $=$ adjusted intensity of $\mathrm{CN}$ array - adjusted intensity of IC array.

$\mathrm{d} \_=$the signal ratio was not calculated when the adjusted intensity is background level in either array.

genearray/). Many of these were consistent with previous literature including neurotransmitter-related genes such as substance $\mathrm{P}$ (Wynne and Robertson 1997). Other genes showing expression, which was expected, include neurotransmitter receptor genes, channel-related genes, synapse-related genes such as the synapsins SYN1 and 2A, and neurotrophic factor receptors such as RET2 (GDNF receptor subunit) and trk B.

Genes with particularly high expression (at least 5 times over background) included $\mathrm{Cu}-\mathrm{Zn}$ SOD, calmodulin, protein kinase $\mathrm{C}$ inhibitor protein 1, clusterin, neuron-specific enolase, secretogranin II, secretogranin V, signal transducer CD 24, carboxypeptidase E, GABA-BR, $\beta$-alanine-sensitive GABA transporter, $\mathrm{Na}^{+} / \mathrm{K}^{+}-\mathrm{ATPase} \alpha 1$, somatostatin, and GAP-43. Several genes, whose expression was expected based on the literature or what is known about IC function, had expression levels above background but fell below our criterion for $100 \%$ over background. They include receptor subunits such as GluR3, D(2) dopamine receptor, AchR M2, RET1, and insulin-like growth factor 1 receptor $\alpha$ and channel related genes such as voltage-gated $\mathrm{Ca}^{2+}$ channel $\alpha 1$, voltage-gated $\mathrm{K}^{+}$channel RK5, $\mathrm{Na}^{+}$channel 6, and G-protein-activated $\mathrm{K}^{+}$ inward rectifier.

\section{Comparison of IC and $\mathrm{CN}$}

When expression in the $\mathrm{CN}$ was compared with expression in the IC, there were several genes that had a significant difference in expression between the two regions. The CN showed higher expression in GlyR $\alpha 1$ than the IC and the IC expressed a higher level of GABA-AR $\beta 1$ and GABA-AR $1 \mathrm{a} / 1 \mathrm{~b}$ than the $\mathrm{CN}$, consistent with the literature (Sato et al. 2000a, 2000b). $\mathrm{Na}^{+} / \mathrm{K}^{+}-$ATPase $\alpha 1$ and $\beta 3$ subunits were expressed more highly in the IC while $\beta 2$ was expressed more highly in the CN. Other genes differentially expressed between the two regions include signal transducer CD24, IGFBP-2, SYB 1, cardiac delayed-rectifier $\mathrm{K}^{+}$ channel protein, and GAP43 (Table 2).

Comparison of auditory regions and the hippocampus

Each region of the auditory pathway was compared separately to the HP. A greater number of differentially expressed genes were identified when comparing the peripheral (cochlear) regions with the central regions (CN, IC, HP) than when comparing the three central regions. For instance, there were many more genes with significant differences in expression when the WC was compared with the HP (Fig. 3B and Table 4) than when the IC was compared to the HP (Fig. 3A and Table 3). Two central auditory regions were compared; although there were a few more genes differentially expressed between the IC and the $\mathrm{CN}$ (Fig. 3C and Table 2) than between the IC and the HP, the comparison patterns of IC vs. HP and $\mathrm{CN}$ vs. IC were very similar. The comparison patterns of WC vs. IC (Fig. 3D) and WC vs. HP (Fig. 3B) were very similar as well.

In general, the expression patterns of proto-oncogenes, signaling molecules, and metabolic enzymes were similar in the CNS and cochlear regions, although a few genes showed distinct expression among regions, such as $\mathrm{p} 27^{\mathrm{Kip} 1}$ (A5n) in the cochlear regions and cell adhesion kinase $\beta$ (B41) in the HP. 

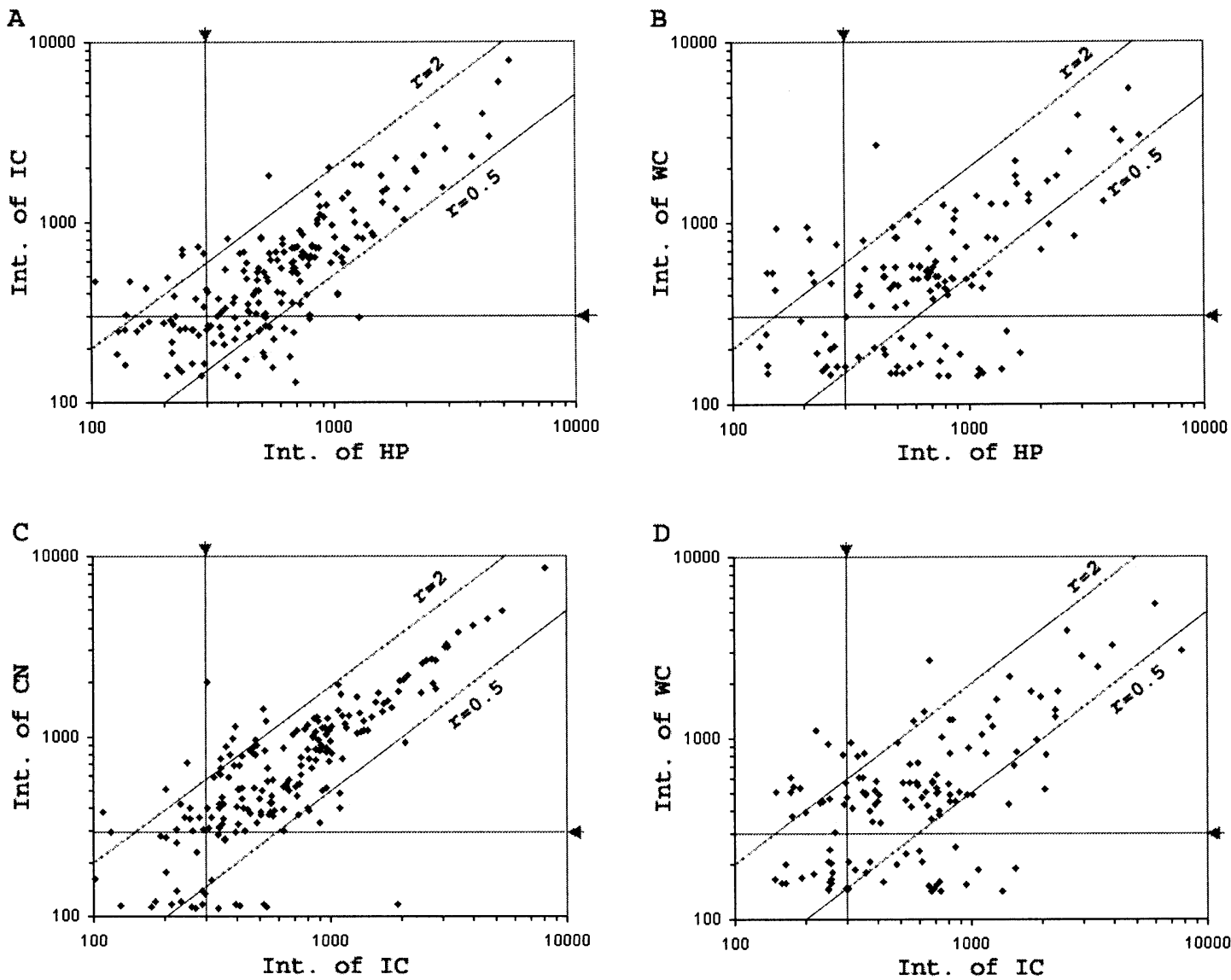

FIG. 3. Comparison of gene expression profiles. Two central auditory regions and the whole cochlea were compared with either the hippocampus $(\mathrm{HP})(\mathbf{A}, \mathbf{B})$ or to the inferior colliculus $(\mathbf{C}, \mathbf{D})$. Twofold changes $(r=$ intensity in array 2 /intensity in array $1>2$ or $<0.5)$ are indicated. The arrow indicates the signal threshold (twice background) of each membrane.

\section{TABLE 3}

\begin{tabular}{|c|c|c|c|}
\hline \multicolumn{4}{|c|}{ List of genes differentially expressed between the IC and the HPa } \\
\hline Location & Protein/gene & Ratio $^{\mathrm{b}}$ & Difference ${ }^{\mathrm{c}}$ \\
\hline & Higher expression in the IC compared with the HP & & \\
\hline E7j & Beta-alanine-sensitive neuronal GABA transporter & 3.3 & 1256 \\
\hline C7d & Secretogranin II precursor (SGII; SCG2); chromogranin C (CHGC) & 2.1 & 1040 \\
\hline & ower expression in the IC compared with the HP & & \\
\hline B4l & Cell adhesion kinase beta (CAK beta); calcium-dependent; FAK family & 0.1 & -1145 \\
\hline C7I & Glutamate receptor 1 precursor (GluR-1); GluR-A; GluR-K1 & 0.2 & -987 \\
\hline B5j & Transducin beta- 1 subunit; GTP-binding protein $\mathrm{G}(\mathrm{i}) / \mathrm{G}(\mathrm{s}) / \mathrm{G}(\mathrm{t})$ beta subunit 1 & 0.4 & -651 \\
\hline B6a & Ras-related protein Rab2 & 0.4 & -632 \\
\hline $\mathrm{E} 7 \mathrm{~g}$ & Ehk 3; ephrin type-A receptor 7; tyrosine kinase (Eph-related); EphA7 & $-{ }^{d}$ & -752 \\
\hline
\end{tabular}

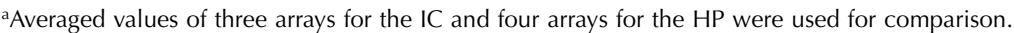

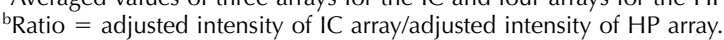

${ }^{\mathrm{C}}$ Difference $=$ adjusted intensity of IC array - adjusted intensity of HP array.

$\mathrm{d} \_=$the signal ratio was not calculated when the adjusted intensity is background level in either array.

However, the expression patterns of apoptosis-related genes and neuronal genes, growth factor receptors and channels, and proteases and inhibitors were very different between CNS and the cochlear regions. The cochlear regions expressed two types of myelin proteins: PLP (C3f) and PMP-22 (C3h), while CNS expressed largely PLP. The cochlear regions showed a high level of expression in TGF $\beta$ II receptor (E1n) and sensory neuron-specific proton gated cation channel (E6n), while the CNS expressed high levels of glutamate transporter (E6i) and GABA transporter (E7j). The CNS expressed a high level of somatostatin 


\begin{tabular}{|c|c|c|c|}
\hline \multicolumn{4}{|c|}{ List of genes differentially expressed between the WC and the $\mathrm{HP}^{\mathrm{a}}$} \\
\hline Location & Protein/gene & Ratio $^{\mathrm{b}}$ & Difference $^{\mathrm{c}}$ \\
\hline \multicolumn{4}{|c|}{ Higher expression in the WC compared with the HP } \\
\hline $\mathrm{C} 3 \mathrm{~h}$ & SR13 myelin protein; peripheral myelin protein 22 (PMP-22); CD25 protein & 6.6 & 2295 \\
\hline A5n & p2 $27^{\text {Kip1 }}$ & 6.0 & 776 \\
\hline $\mathrm{F} 6 \mathrm{~b}^{\mathrm{e}}$ & Metaloproteinase inhibitor 3 precursor; tissue inhibitor of metalloproteinase 3 (TIMP3) & 4.6 & 750 \\
\hline D2a & Fatty acid-binding protein (heart; H-FABP) & 3.8 & 599 \\
\hline $\mathrm{F} 2 \mathrm{~b}^{\mathrm{e}}$ & Insulin-like growth factor-binding protein (rIGFBP6) & $-^{d}$ & 970 \\
\hline E1n & Transforming growth factor-beta II receptor precursor (TGF-beta II receptor; TGFBR2) & - & 825 \\
\hline E6n & Proton gated cation channel drasic; "AQ6" sensory neuron specific & - & 757 \\
\hline $\mathrm{F} 4 \mathrm{~d}^{\mathrm{e}}$ & Matrix metalloproteinase 14 (MMP14); membrane-type MMP 1 (MT-MMP1) & - & 698 \\
\hline D3f & Lecithin:cholesterol acyltransferase (EC 2.3.1.43; LCAT) & - & 606 \\
\hline E2k & Insulin receptor precursor (INSR; IR) & - & 605 \\
\hline $\mathrm{F} 6 \mathrm{i}^{\mathrm{e}}$ & Gelatinase A & 11 & 447 \\
\hline \multicolumn{4}{|c|}{ Lower expression in the WC compared with the HP } \\
\hline B6i & 14-3-3 protein zeta/delta; PKC inhibitor protein-1 & 0.4 & -2432 \\
\hline F5i & Carboxypeptidase E; carboxipeptidase $\mathrm{H}$ & 0.3 & -1992 \\
\hline $\mathrm{C} 7 \mathrm{k}$ & GABA-B receptor $1 \mathrm{a}+\mathrm{GABA}-\mathrm{B}$ receptor $1 \mathrm{~b}$ & 0.1 & -1469 \\
\hline C5e & Neuroendocrine protein 7B2 precursor; secretogranin V; SGNE1 & 0.4 & -1316 \\
\hline C5d & Neuron-specific enolase (NSE); gamma enolase (EC 4.2.1.11) & 0.5 & -1224 \\
\hline C4l & N-methyl-D-aspartate receptor (NMDAR1); glutamate receptor subunit zeta 1 precursor & 0.1 & -1219 \\
\hline C5j & Synapsins IA and IB (SYN1) & 0.2 & -1200 \\
\hline B3i & Extracellular signal-regulated kinase 2 (ERK2); mitogen-activated protein kinase 2 & 0.1 & -995 \\
\hline B4d & Protein kinase C beta-I type (PKC-beta I) + protein kinase C beta-II type (PKC-beta II) & 0.1 & -954 \\
\hline F5a & Dipeptidyl aminopeptidase-related protein (DPP6) & 0.1 & -944 \\
\hline E3c & Calcium-independent alpha-latrotoxin receptor & 0.2 & -733 \\
\hline B5i & Guanine nucleotide-binding protein alpha 12 subunit (G alpha 12; GNA12) & 0.4 & -720 \\
\hline C6g & PMCA; ATP2B2; calcium-transporting ATPase plasma membrane (brain isoform 2) & 0.4 & -705 \\
\hline $\mathrm{C} 3 \mathrm{k}$ & G protein beta-adrenergic receptor kinase 1 (beta-ARK1; EC 2.7.1.126) & 0.2 & -671 \\
\hline D5i & SHPS-1 receptor-like protein with $\mathrm{SH} 2$ binding site & 0.2 & -608 \\
\hline C5k & Synapsin $2 \mathrm{~A}$ & - & -1967 \\
\hline E6i & ǴluT and GluT-R glutamate transporter & - & -1327 \\
\hline $\mathrm{C} 7 \mathrm{I}$ & Glutamate receptor 1 precursor (GluR-1); GluR-A; GluR-K1 & - & -1279 \\
\hline B4I & Cell adhesion kinase beta (CAK beta); calcium-dependent; FAK family & - & -1227 \\
\hline $\mathrm{C} 7 \mathrm{f}$ & Synaptobrevin 2 (SYB2); vesicle-associated membrane protein 2 (VAMP2) & - & -1218 \\
\hline B4g & Protein kinase C epsilon type (PKC-epsilon) & - & -1095 \\
\hline D6b & Glutamate receptor 2 precursor (GLUR-2; GLUR-B; GLUR-K2) & - & -1029 \\
\hline C6i & Glia maturation factor beta (GMF-beta; GMFB) & - & -1017 \\
\hline $\mathrm{C} 7 \mathrm{~d}$ & Secretogranin II precursor (SGIl; SCG2); chromogranin C (CHGC) & - & -957 \\
\hline F2l & Somatostatin & - & -944 \\
\hline $\mathrm{C} 4 \mathrm{~h}$ & Neuromodulin; axonal membrane protein GAP43 & - & -871 \\
\hline D5c & Elongation factor SIII P15 subunit & - & -835 \\
\hline A3i & c-Kit proto-oncogene & - & -773 \\
\hline B5m & Ras-related protein m-ras & - & -765 \\
\hline B7j & PKI-alpha; cAMP-dependent protein kinase inhibitor (muscle/brain form) & - & -734 \\
\hline E6e & Proton-coupled dipeptide cotransporter & - & -729 \\
\hline F5g & Proteasome subunit RC10-II & - & -688 \\
\hline $\mathrm{F} 5 \mathrm{~b}$ & Proteasome delta subunit precursor; macropain delta & - & -679 \\
\hline A4d & $\mathrm{c}-\mathrm{H}$-ras proto-oncogene; transforming G-protein p21 & - & -678 \\
\hline A4f & c-K-ras 2 b proto-oncogene; transforming G-protein p21 & - & -611 \\
\hline D1c & Epidermal fatty acid-binding protein (E-FABP); cutaneous fatty acid-binding protein & - & -607 \\
\hline
\end{tabular}

${ }^{a}$ Averaged values of two arrays for the WC and four arrays for the HP were used for comparison.

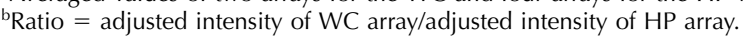

${ }^{c}$ Difference $=$ adjusted intensity of WC array - adjusted intensity of HP array.

$\mathrm{d}$ - $=$ the signal ratio was not calculated when the adjusted intensity is the background level in either array.

${ }^{\mathrm{e}}$ Genes chosen for RT-PCR assay.

(F21), dipeptidyl aminopeptidase-related protein (F5a), and carboxypeptidase E/H (F5i). However, the cochlear regions expressed a high level of IGFBP-6
(F2b), MT-MMP 1 (F4d), and TIMP-3 (F6b). The filter hybridization images of six regions are available on our webpage (www.khri.med.umich.edu/genearray/). 


\section{RT-PCR analysis}

RT-PCR was used to verify expression of six genes that showed higher expression in the cochlear regions than in the CNS regions and that had not been previously reported to be expressed in the cochlea: LIMK-1, IGFBP-2, IGFBP-6, gelatinase A/MMP-2, MT MMP-1/ MMP-14, and TIMP-3. The differences in the expression levels of IGFBP-6, MT MMP-1, and TIMP-3 were large enough to meet our criteria for a significant difference; twofold ratio and twofold background in signal difference (Table 4). RT-PCR confirmed that these three genes were highly expressed in the cochlear regions (Fig. 4). IGFBP-2 was differentially expressed between the MOD and the SE in the gene array study (Table 1) and RT-PCR confirmed the highest expression level of IGFBP-2 in the SE (Fig. 4). Gelatinase A was also chosen for RT-PCR verification, although the expression difference between the WC and the HP did not meet the criteria. RT-PCR revealed a high expression of gelatinase $\mathrm{A}$ in the cochlear regions and the $\mathrm{CN}$. The expression level of gelatinase A was in fact not detectable in the IC and HP but detectable with a significant level of intensity in the cochlear regions and the CN. This example shows that while our stringent threshold for a significant difference provides for high confidence in the results, it can allow genes with a small difference between two regions to be missed. LIMK-1 was expressed at high level in the WC and the modiolar subfraction. Our studies that used membranes with a larger number of genes (unpublished data) showed that the WC expressed a high level of cofilin that is phosphorylated only by LIMK-1 (Yang et al. 1998). LIMK-1 and cofilin are known to be involved in the actin dynamics (Arber et al. 1998). RT-PCR confirmed the higher expression of LIMK-1 in the cochlear regions than in the CNS (Fig. 4).

\section{DISCUSSION}

These gene expression profiling studies detected expression of genes in the cochlea, $\mathrm{CN}$, and IC that had not previously been reported. For example, Crk adapter protein, syntaxin binding protein, Sec1, clusterin, TIMP-2, and others were expressed at high levels in all auditory regions examined in this study. Our gene expression data are largely consistent with previous studies. We could detect genes, such as p27 Kip1 and $\mathrm{P} 2 \mathrm{X}(2)$ receptor, whose expression was previously reported in the whole cochlea. TIMP-3, PMP-22, TGFBR2 and 3, and others were also reported in the human fetal cochlear cDNA library. This gene profiling study also revealed differences in gene expression among the six regions tested. We found, not unexpectedly, greater differences between the CNS regions and the cochlea than between the auditory and nonauditory brain regions. These facts suggest that even small subsets of genes can provide fruitful information of gene expression profiles.

\section{Neurotransmitter receptors}

Our gene expression profiles showed differences among the HP, IC, and CN in the expression of many neurotransmitter-related genes, and these results were consistent with previous findings. The neurotransmitter receptor genes reported as positive are indeed those which have been reported to have high expression, such as NMDAR1 (Barnes-Davies and Forsythe 1995; Bilak et al. 1996; Kuriyama et al. 1993; Niedzielski et al. 1997; Safieddine and Eybalin 1992; Sato et al. 1998). The CN has low expression of GluR1 compared with other regions (Hunter et al. 1993). The HP shows a much higher expression of GluR1 than the IC (Wenthold et al. 1996). There is high glycinergic input to the CN compared with the HP with the IC intermediate and no known glycinergic input to the cochlea (Altschuler et al. 1986a, 1986b; Sato et al. 1995, 2000a). The GlyR $\alpha 1$ subunit is expressed more highly in the $\mathrm{CN}$ than in the IC and below the threshold in the HP and cochlear regions. GABA is well represented in the IC and HP, with inputs also present in the CN and cochlea (Altschuler et al. 1986b; Sato el al. 2000b). The HP and the IC had the greatest expression of GABA-AR subunits, with the $\beta 2$ subunit highest in the IC. While no GABA-AR subunit was detected in cochlear fractions, the GABA-B $1 \mathrm{a} / 1 \mathrm{~b}$ receptor was expressed in the MOD and WC, consistent with the literature (Siddique et al. 2000). The GABA-B 1a/1b receptor was also very highly expressed in the $\mathrm{HP}, \mathrm{IC}$, and $\mathrm{CN}$.

The SE subfraction expressed the P2X(2) receptor but the MOD did not, suggesting a role in the organ of Corti or stria vascularis, consistent with previous reports (Housley et al. 1999; Jarlebark et al. 2000). It was not expressed above our threshold for any of the brain regions assessed. The positive expression of somatostatin in the IC and $\mathrm{CN}$ and of substance $\mathrm{P}$ in the IC but not in the $\mathrm{CN}$ is consistent with previous reports of their expression in these areas (Wynne et al. 1995; Wynne and Robertson 1997).

\section{Cyclins, CDKs, and CKIs; p2 $7^{\text {Kip1 }}$}

The Atlas Rat cDNA Expression Array contains genes for seven cyclins (A4n-A5f), five CDKs (A5g-A5k), and four CKIs (A5l-A6a). Most of these genes were expressed at a low level in all six regions, whereas p2 $7^{\mathrm{Kip} 1}$, one of the CKIs, was detected at a higher level in the cochlea and its subregions than any other CNS regions examined in this study. 
A

LIMK-1

IGFBP-2

IGFBP -6

TTMP -3

MT MMP-1

Gelatinase A

Beta-actin

Polyubiquitin

\section{HP IC CN พC MOD \\ $\mathrm{SE}$

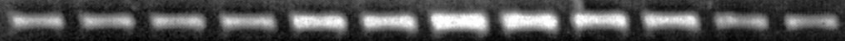

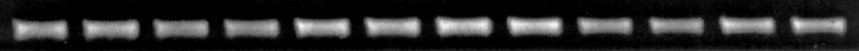

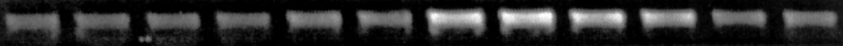

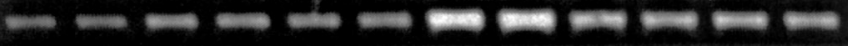
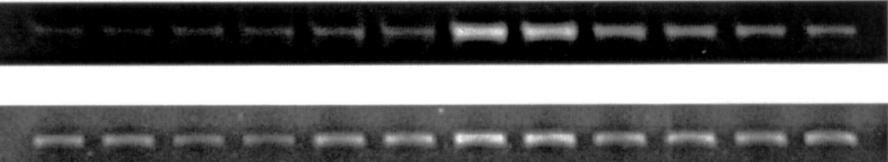

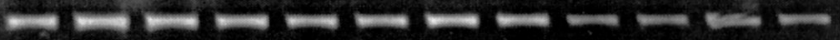

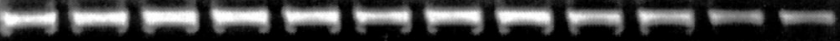

B
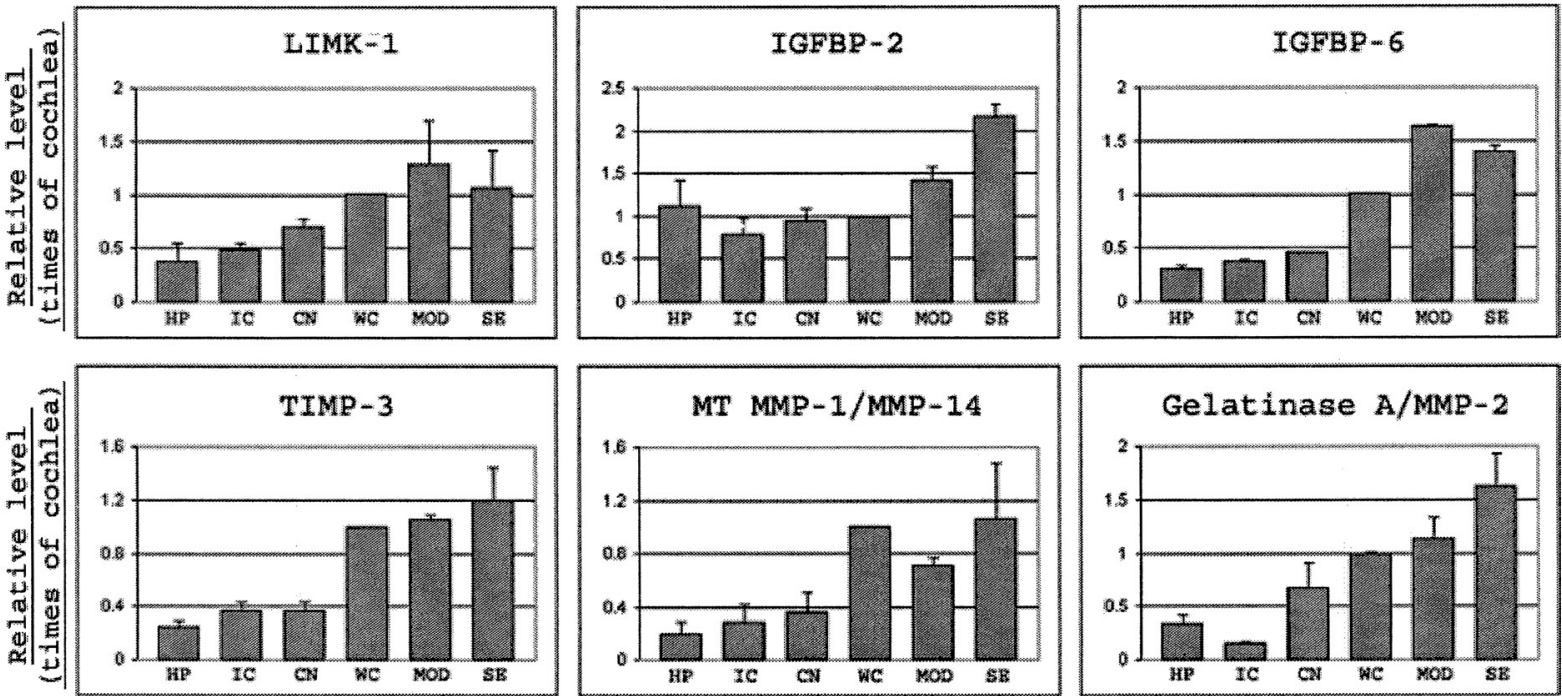

FIG. 4. RT-PCR analysis of mRNA expression in the auditory regions and the hippocampus. RT-PCR assay was performed on the total RNA from the hippocampus (HP), the inferior colliculus (IC), the cochlear nucleus $(\mathrm{CN})$, the whole cochlea (WC), the modiolus (MOD), or the sensorineural epithelium (SE) for mRNA expression of the indicated genes. A Agarose gene electrophoresis of PCR products. Aliquots (10 $\mu \mathrm{L}$ ) of the PCR reactions were loaded in duplicate onto agarose gels. The PCR reactions were sampled at 30 cycles for the first six genes

Many roles have been assigned to $\mathrm{p} 27^{\mathrm{Kip} 1}$ such as tumor suppressor and cell differentiation factor. Decreased expression level of $\mathrm{p} 27^{\mathrm{Kipl}}$ is associated with several human cancers (Lloyd et al. 1999). p27 Kip1 deficient mice in adulthood are larger than normal mice without gross morphological deformation and and at 25 and 27 cycles for $\beta$-actin and polyubiquitin, respectively. B Quantitative analysis of the PCR products. The value of the mean + standard deviation from two or three PCR experiments is plotted. The raw intensity volumes of the PCR bands obtained from IPLab software were converted into a relative value to the whole cochlea (the intensity of the whole cochlea is given as 1 ) and then normalized to the housekeeping genes $\beta$-actin and polyubiquitin.

they develop pituitary tumors at a later stage in life (Fero et al. 1996; Kiyokawa et al. 1996; Nakayama et al. 1996). Recent studies on the knockout mice reported that $\mathrm{p} 27^{\mathrm{Kip}-/}$ mice have abnormal morphology in the organ of Corti (supernumerary hair cells and supporting cells) and impaired hearing with 30- 
$50 \mathrm{~dB}$ shifts throughout broad ranges of hearing frequency (Chen and Segil 1999; Lowenheim et al. 1999). The expression of $\mathrm{p} 27^{\mathrm{Kip} 1}$ in the primordial organ of Corti is detected between E12 and E14 when the developing hair cells and supporting cells undergo their terminal division; p27 $7^{\text {Kipl }}$ continues to be expressed in the supporting cells of adult animals (Chen and Segil 1999). These studies suggest an important role of p27 ${ }^{\text {Kipl }}$ in inner-ear development. Our gene profile results strengthen the conclusion that $\mathrm{p} 27^{\mathrm{Kip} 1}$ is also important in the mature ear. Since the expression of p27 $7^{\text {Kip1 }}$ is limited to supporting cells in the organ of Corti, determination of the p2 $7^{\text {Kipl }}$ cellular localization in the modiolus will be valuable.

\section{MMPs and TIMPs}

Matrix metalloproteinases (MMPs) are proteolytic enzymes that degrade extracellular matrix (ECM) proteins such as collagens and proteoglycans, and TIMPs regulate the activity of MMPs. MMPs and TIMPs are also regulated at the level of transcription, which means an environmental stimulus can modulate the expression level. These complex aspects subject MMPs to a very precise temporal and spatial control (Crawford and Matrisian 1996).

The Atlas Rat cDNA Expression Array includes six MMPs: MMP-2 (F6i), MMP-7 (F4b), MMP-10 (A4m), MMP-11 (C2n), MMP-14 (F4d), and MMP-16 (F7b) and three TIMPs: TIMP-1 (F4g), TIMP-2 (F4h), and TIMP-3 (F6b). In our gene profiling and RT-PCR assays, MMPs and TIMPs showed distinct expression patterns between three CNS regions and the cochlear tissues; the cochlea expresses exclusively a high level of MMP-2/gelatinase A, MMP-14/MT MMP-1, and TIMP-3 compared with the CNS regions.

Putative physiological functions of the MMP and TIMP system are listed as tissue remodeling, angiogenesis, and wound healing (Yong et al. 1998). MMPs and TIMPs are also highly implicated in human disease such as cancer (Crawford and Matrisian 1996; Okada et al. 1995; Sternlicht et al. 1999) and multiple sclerosis (Yong et al. 1998). MMP-9-/ mice exhibit abnormal angiogenesis and ossification of the skeletal growth plate in young animals (Sternlicht et al. 1999). MMP$14^{-/}$mice have defects in the formation of skeletal connective tissue and die between days 50 and 90 (Holmbeck et al. 1999). Patients with Sorsby's fundus dystrophy (SFD) have a mutation on TIMP-3 (Weber et al. 1994). SFD is a hereditary, autosomal dominant, macular degenerative disease resulting in irreversible visual loss, although it is not clear whether patients with SFD have abnormal hearing or not. The observation that the cochlea expresses a higher level of MMP2, MMP-14, and TIMP-3 mRNAs than the CNS region is intriguing, although the precise function of these proteins in the cochlea is not known yet.

\section{IGFs and IGFBPs}

IGFs are growth factors and the accessibility of IGFs to the tissues is controlled by IGFBPs (Ferry et al. 1999; Rosenfeld et al. 1999; Wetterau et al. 1999). The Atlas Array contains two IGFs: IGF-I (F2j) and IGF-II (F2g), two IGFRs: IGFI-R $\alpha$ (E2b) and IGF-2R (A4l), and four IGFBPs: IGFBP-1 (F1a), -2 (A4k), -3 (F1b), and -6 (F2b). Our profiles showed that the expression pattern of IGFBPs was different between the CNS regions and the cochlea. IGFBP-2 (A4k) was expressed in all six regions but the expression level was highest in the SE subfraction. IGFBP-6 was detected in the cochlea and its subfractions at a very high level but not in the CNS regions. Morton's human fetal cochlear cDNA library reported the expression of IGF-I and IGFBP-1, -3 , and -5 and our gene expression profile showed IGF-2 and IGFBP-2 and -6. The expression of IGFBPs could be regulated at developmental stages (Cerro et al. 1993; Green et al. 1994).

The expression patterns of IGFBPs are also tissuespecific. IGFBP-1 is the major IGFBP in the amniotic fluid, IGFBP-3 in the serum, and IGFBP-2 and -6 in the cerebrospinal fluid (Ferry et al. 1999). The biological functions of the IGFBP complex-IGFBP-2, -4, and -6 - are inhibitory for IGF-I whereas IGFBP-5 potentiates the IGF-I action (Murphy 1998). Some of the IGFBPs are known to have IGF-independent effects as well; IGFBP-1 has an effect on migration of vascular smooth muscle cells in vitro regardless of the presence of IGF-I (Ferry et al. 1999; Murphy 1998). IGFBP-2 was elevated in CSF from children with malignant CNS tumors (Muller et al. 1994). The phenotype of the IGFBP-2 knockout mouse was very subtle (Wood 1995; Wood et al. 1993). Therefore, the evaluation of the physiological roles of IGFBP-2 and -6 in the cochlea will remain for future studies.

\section{Methodological considerations}

One question we had was whether the WC preparation would be biased toward genes expressed in the modiolus, which represents the greatest fraction $(80 \%)$ of the tissue and thus cause us to miss expression of genes specific to the organ of Corti and/or stria vascularis. We found, for the most part, that genes selectively expressed in the SE vs. the MOD could also be detected in the WC. The P2X(2) receptor, the Ear-3 transcription factor, bFGF-R, and IGF II were all detected in both the WC and the SE subfractions but not in the MOD. Thus, we can conclude that most genes expressed in the organ of Corti will be detected in a WC preparation. This may be related to a technical 
advantage of this Clontech gene array. The use of genespecific primers in order to make the radiolabeled cDNA probe could increase the sensitivity. On the other hand, growth hormone was expressed in the SE but was not detected in the MOD or WC. The enrichment provided by subdividing may be necessary to see less abundantly expressed genes. This suggests that a further subdivision of the SE into enriched organ of Corti and lateral wall subfractions might be of benefit in future studies.

Clearly, our results identified many genes with low expression that fall below the threshold levels that we set. Several neurotransmitter receptors were reported as expressed in auditory brainstem regions were detected but were below the threshold in this study. For example, expression of GluR 2/3 has been shown in spiral ganglion cells of the cochlea (Niedzielski et al. 1995); however, expression in WC or MOD preparations was below our threshold in the current study. Therefore, it is important that a negative result in the current study not be interpreted to mean that there is no expression of that gene. All that can be concluded is that the expression is relatively low compared with genes that could be detected by this method.

\section{CONCLUSION}

Normal gene expression profiling using gene arrays provides a global picture of the biology of a specific region, and the differences in gene expression among regions reflect the morphological and functional differences among tissues. We believe that gene expression profiling will help us to understand the biological events occurring in the auditory system under normal conditions and to follow abnormal stimuli resulting from environmental stresses or from disease states.

\section{ACKNOWLEDGMENT}

This research was supported by NIDCD program project grant (\#PO1 DC02982).

\section{REFERENCES}

Altschuler RA, Betz H, Parakkal MH, Reeks KA, Wenthold RJ. Identification of glycinergic synapses in the cochlear nucleus through immunocytochemical localization of the postsynaptic receptor. Brain Res. 369:316-320, 1986a.

Altschuler RA, HofFmAn DW, Wenthold RJ. Neurotransmitters of the cochlea and cochlear nucleus: immunocytochemical evidence. Am. J. Otolaryngol. 7:100-106, 1986b.

Altschuler RA, ReEks KA, Marangos PJ. Neuron-specific enolaselike immunoreactivity in inner hair cells but not outer hair cells in the guinea pig organ of Corti. Brain Res. 327:379-384, 1985. Arber S, Barbayannis FA, Hanser H, Schneider C, Stanyon CA,
BERNARD O, CARONI P. Regulation of actin dynamics through phosphorylation of cofilin by LIM-kinase [see comments]. Nature 393:805-309, 1998.

BARneS-DAVIES M, ForsYThe ID. Pre- and postsynaptic glutamate receptors at a giant excitatory synapse in rat auditory brainstem slices. J. Physiol. 488:387-406, 1995.

BILAK MM, BILAK SR, MOREST DK. Differential expression of Nmethyl-D-aspartate receptor in the cochlear nucleus of the mouse. Neuroscience 75:1075-1087, 1996.

Cerro JA, Grewal A, Wood TL, Pintar JE. Tissue-specific expression of the insulin-like growth factor binding protein (IGFBP) mRNAs in mouse and rat development. Regul. Pept. 48:189198, 1993.

CHen P, SegIL N. p27(Kip1) links cell proliferation to morphogenesis in the developing organ of Corti. Development 126:1581$1590,1999$.

CHOMCZYNSKI P, SACCHI N. Single-step method of RNA isolation by acid guanidinium thiocyanate-phenol-chloroform extraction. Anal. Biochem. 162:156-159, 1987.

Chu S, DeRisi J, Eisen M, Mulholland J, Botstein D, Brown PO, Herskowitz I. The transcriptional program of sporulation in budding yeast. Science 282:699-705, 1998.

CraWFord HC, MATRISIAN LM. Mechanisms controlling the transcription of matrix metalloproteinase genes in normal and neoplastic cells. Enzyme Protein 49:20-37, 1996.

el Barbary A, Altschuler RA, Schacht J. Glutathione S-transferases in the organ of Corti of the rat: enzymatic activity, subunit composition and immunohistochemical localization. Hear. Res. 71:80-90, 1993.

Fero ML, Rivkin M, Tasch M, Porter P, Carow CE, Firpo E, Polyak K, Tsai LH, Broudy V, Perlmutter RM, Kaushansky K, ROBERTS JM. A syndrome of multiorgan hyperplasia with features of gigantism, tumorigenesis, and female sterility in p27(Kip1)deficient mice. Cell 85:733-744, 1996.

FERRY RJ JR, CERRI RW, COHEN P. Insulin-like growth factor binding proteins: new proteins, new functions. Horm. Res. 51:53-67, 1999.

Friauf E, HAmmerschmidt B, Kirsch J. Development of adult-type inhibitory glycine receptors in the central auditory system of rats. J. Comp. Neurol. 385:117-134, 1997.

Gong TW, Hegeman AD, Shin JJ, Adler HJ, Raphael Y, Lomax MI. Identification of genes expressed after noise exposure in the chick basilar papilla. Hear. Res. 96:20-32, 1996.

Green BN, Jones SB, Streck RD, Wood TL, Rotwein P, Pintar JE. Distinct expression patterns of insulin-like growth factor binding proteins 2 and 5 during fetal and postnatal development. Endocrinology 134:954-962, 1994.

Hafidi A, MoOre T, SANES DH. Regional distribution of neurotrophin receptors in the developing auditory brainstem. J. Comp. Neurol. 367:454-464, 1996.

Holmbeck K, Bianco P, Caterina J, Yamada S, Kromer M, Kuznetsov SA, Mankani M, Robey PG, Poole AR, Pidoux I, Ward JM, BIRKEDAL-HANSEN H. MT1-MMP-deficient mice develop dwarfism, osteopenia, arthritis, and connective tissue disease due to inadequate collagen turnover. Cell 99:81-92, 1999.

Housley GD, Kanjhan R, Raybould NP, Greenwood D, Salih SG, Jarlebark L, Burton LD, Setz VC, Cannell MB, Soeller C, Christie DL, Usami S, Matsubara A, Yoshie H, Ryan AF, Thorne PR. Expression of the P2X(2) receptor subunit of the ATP-gated ion channel in the cochlea: implications for sound transduction and auditory neurotransmission. J. Neurosci. 19:8377-8388, 1999.

Hunter C, Petralia RS, Vu T, Wenthold RJ. Expression of AMPAselective glutamate receptor subunits in morphologically defined neurons of the mammalian cochlear nucleus. J. Neurosci. 13:1932-1946, 1993.

JARlebark LE, Housley GD, Thorne PR. Immunohistochemical localization of adenosine $5^{\prime}$-triphosphate-gated ion channel 
$\mathrm{P} 2 \mathrm{X}$ (2) receptor subunits in adult and developing rat cochlea. J. Comp. Neurol. 421:289-301, 2000.

Juiz JM, Albin RL, Helfert RH, Altschuler RA. Distribution of GABAA and GABAB binding sites in the cochlear nucleus of the guinea pig. Brain Res. 639:193-201, 1994.

Kiyokawa H, Kineman RD, Manova-Todorova KO, Soares VC, Hoffman ES, Ono M, Khanam D, Hayday AC, Frohman LA, KofF A. Enhanced growth of mice lacking the cyclin-dependent kinase inhibitor function of p27(Kip1). Cell 85:721-732, 1996.

Kuriyama H, Albin RL, Altschuler RA. Expression of NMDAreceptor mRNA in the rat cochlea. Hear. Res. 69:215-220, 1993.

Lloyd RV, Erickson LA, Jin L, Kulig E, Qian X, CheVille JC, SCHEITHAUER BW. p27kip1: a multifunctional cyclin-dependent kinase inhibitor with prognostic significance in human cancers. Am. J. Pathol. 154:313-323, 1999.

Lowenheim H, Furness DN, Kil J, Zinn C, Gultig K, Fero ML, Frost D, Gummer AW, Roberts JM, Rubel EW, Hackney CM, ZENNER HP. Gene disruption of p27 (Kip1) allows cell proliferation in the postnatal and adult organ of Corti. Proc. Natl. Sci. U S A 96:4084-4088, 1999.

Muller HL, OH Y, Lehrnbecher T, Blum WF, Rosenfeld RG. Insulin-like growth factor-binding protein-2 concentrations in cerebrospinal fluid and serum of children with malignant solid tumors or acute leukemia. J. Clin. Endocrinol. Metab. 79:428434, 1994.

MURPHY LJ. Insulin-like growth factor-binding proteins: functional diversity or redundancy? J. Mol. Endocrinol. 21:97-107, 1998.

Nakayama K, Ishida N, Shirane M, Inomata A, Inoue T, Shishido N, HORII I, LOH DY. Mice lacking p27(Kip1) display increased body size, multiple organ hyperplasia, retinal dysplasia, and pituitary tumors. Cell 85:707-720, 1996.

NiEdziELSKi AS, SAFieddine S, Wenthold RJ. Molecular analysis of excitatory amino acid receptor expression in the cochlea, Audiol. Neurootol. 2:79-91 1997, [erratum: Audiol. Neurootol. 1997; 2(4):231].

NIEDZIELSKI AS, WENTHOLD RJ. Expression of AMPA, kainate, and NMDA receptor subunits in cochlear and vestibular ganglia. J. Neurosci. 15:2338-2353, 1995.

Okada A, Belloce JP, Rouyer N, Chenard MP, Rio MC, Chambon P, BASSET P. Membrane-type matrix metalloproteinase (MT-MMP) gene is expressed in stromal cells of human colon, breast, and head and neck carcinomas. Proc Natl Acad Sci U S A 92:27302734, 1995.

Robertson NG, Khetarpal U, Gutierrez-Espeleta GA, Bieber FR, Morton CC. Isolation of novel and known genes from a human fetal cochlear cDNA library using subtractive hybridization and differential screening. Genomics 23:42-50, 1994.

Rosenfeld RG, Hwa V, Wilson L, LOPEZ-Bermejo A, Buckway C, Burren C, Choi WK, Devi G, Ingermann A, Graham D, Minniti G, Spagnoli A, OH Y. The insulin-like growth factor binding protein superfamily: new perspectives. Pediatrics 104:10181021, 1999.

SAFIEDDINE S, EYBALIN M. Co-expression of NMDA and AMPA/kainate receptor mRNAs in cochlear neurones. Neuroreport 3:11451148, 1992.
SATO K, Kuriyama H, Altschuler RA. Expression of glycine receptor subunits in the cochlear nucleus and superior olivary complex using non-radioactive in-situ hybridization. Hear. Res. 91:7-18, 1995.

Sato K, Kuriyama H, Altschuler RA. Differential distribution of NMDA receptor subunit mRNA in the rat cochlear nucleus. Microsc. Res. Tech. 41:217-223, 1998.

Sato K, Kuriyama H, Altschuler RA. Expression of glycine receptor subunit mRNAs in the rat cochlear nucleus. Hear. Res. 144:4752, 2000a.

Sato K, Shiraishi S, Nakagawa H, Kuriyama H, Altschuler RA. Diversity and plasticity in amino acid receptor subunits in the rat auditory brain stem. Hear. Res. 147:137-144, 2000b.

Siddique S, Drescher M, Khan K, Hatfield J, Drescher D. Expression of GABA-B receptor subunit transcript and protein in the rat cochlea and microdissected subfractions. Abstr. Assoc. Res. Otolaryngol. 23:465, 2000.

Skvorak AB, Weng Z, Yee AJ, Robertson NG, Morton CC. Human cochlear expressed sequence tags provide insight into cochlear gene expression and identify candidate genes for deafness. Hum. Mol. Genet. 8:439-452, 1999.

Sternlicht MD, Lochter A, Sympson CJ, Huey B, Rougier JP, Gray JW, Pinkel D, Bissell MJ, Werb Z. The stromal proteinase MMP3/Stromelysin-1 promotes mammary carcinogenesis. Cell 98:137-146, 1999.

Weber BH, Vogt G, Pruett RC, Stohr H, Felbor U. Mutations in the tissue inhibitor of metalloproteinases-3 (TIMP-3) in patients with Sorsby's fundus dystrophy. Nat. Genet. 8:352-356, 1994.

Wenthold RJ, Petralia RS, Blahos J II, Niedzielski AS. Evidence for multiple AMPA receptor complexes in hippocampal CA1/ CA2 neurons. J. Neurosci. 16:1982-1989, 1996.

Wetterau LA, Moore MG, Lee KW, Shim ML, Cohen P. Novel aspects of the insulin-like growth factor binding proteins. Mol. Genet. Metab. 68:161-181, 1999.

WoOD TL. Gene-targeting and transgenic approaches to IGF and IGF binding protein function. Am. J. Physiol. 269:E613-E622, 1995.

Wood Tl, Rogler L, Streck RD, Cerro J, Green B, Grewal A, PINTAR JE. Targeted disruption of IGFBP-2 gene. Growth Regul. 3:5-8, 1993.

Wynne B, Harvey AR, Robertson D, Sirinathingingu DJ. Neurotransmitter and neuromodulator systems of the rat inferior colliculus and auditory brainstem studied by in situ hybridization. J. Chem. Neuroanat. 9:289-300, 1995.

Wynne B, Robertson D. Somatostatin and substance P-like immunoreactivity in the auditory brainstem of the adult rat. J. Chem. Neuroanat. 12:259-266, 1997.

Yang N, Higuchi O, Ohashi K, Nagata K, Wada A, Kangawa K, Nishida E, Mizuno K. Cofilin phosphorylation by LIM-kinase 1 and its role in Rac-mediated actin reorganization [see comments]. Nature 393:809-812, 1998

Ylikoski J, Pirvola U, Moshnyakov M, Palgi J, Arumae U, SaArma M. Expression patterns of neurotrophin and their receptor mRNAs in the rat inner ear. Hear. Res. 65:69-78, 1993.

Yong VW, Krekoski CA, Forsyth PA, Bell R, Edwards DR. Matrix metalloproteinase and diseases of the CNS. Trends Neurosci. 21:75-80, 1998. 